\title{
Nutritional Aspects of Essential Trace Elements in Oral Health and Disease: An Extensive Review
}

\author{
Preeti Tomar Bhattacharya, ${ }^{1}$ Satya Ranjan Misra, ${ }^{2}$ and Mohsina Hussain ${ }^{1}$ \\ ${ }^{1}$ Department of Oral Medicine and Radiology, Haldia Institute of Dental Sciences and Research, Haldia, West Bengal 721645, India \\ ${ }^{2}$ Department of Oral Medicine and Radiology, Institute of Dental Sciences, Bhubaneswar, Orissa 753001, India
}

Correspondence should be addressed to Preeti Tomar Bhattacharya; preeti_kgmu@rediffmail.com

Received 31 December 2015; Accepted 31 May 2016

Academic Editor: Susana Zeni

Copyright (C) 2016 Preeti Tomar Bhattacharya et al. This is an open access article distributed under the Creative Commons Attribution License, which permits unrestricted use, distribution, and reproduction in any medium, provided the original work is properly cited.

\begin{abstract}
Human body requires certain essential elements in small quantities and their absence or excess may result in severe malfunctioning of the body and even death in extreme cases because these essential trace elements directly influence the metabolic and physiologic processes of the organism. Rapid urbanization and economic development have resulted in drastic changes in diets with developing preference towards refined diet and nutritionally deprived junk food. Poor nutrition can lead to reduced immunity, augmented vulnerability to various oral and systemic diseases, impaired physical and mental growth, and reduced efficiency. Diet and nutrition affect oral health in a variety of ways with influence on craniofacial development and growth and maintenance of dental and oral soft tissues. Oral potentially malignant disorders (OPMD) are treated with antioxidants containing essential trace elements like selenium but even increased dietary intake of trace elements like copper could lead to oral submucous fibrosis. The deficiency or excess of other trace elements like iodine, iron, zinc, and so forth has a profound effect on the body and such conditions are often diagnosed through their early oral manifestations. This review appraises the biological functions of significant trace elements and their role in preservation of oral health and progression of various oral diseases.
\end{abstract}

\section{Introduction}

Appropriate nutrition of all the metabolically active cells and tissues is essential for preserving health of the human body as a whole. Micronutrients, including trace elements, vitamins, and antioxidants, play a vital role in continuously occurring regenerative processes, coping with ongoing oxidative stress in the body tissues, and sustaining ample immunity against pathogens $[1,2]$. The manifestations of undernutrition as well overnutrition of micronutrients on the oral health are vast and can result in defects of the dental hard tissues as well as oral mucosa $[3,4]$.

The word "trace elements" is used for elements existing in natural and perturbed environments in small amounts, with excess bioavailability having a toxic effect on the living organism [5]. Trace elements are chemical micronutrients which are required rather in minute quantity but play a vital role in maintaining integrity of various physiological and metabolic processes occurring within living tissues.
The deficiency of any of the trace elements may be apparent as a combination of various clinical manifestations rather than a specific presentation as each trace element is related to many enzyme systems.

Healthy nutritional habits with regular intake of essential vitamins and minerals are of immense significance to general as well as oral health. As there had been limited knowledge among the oral physicians regarding significance of trace elements in human nutrition, the current review focuses on the role of those essential trace elements which have a proven role in maintaining oral health and their implications in various oral diseases and disorders.

\section{Classifications of Trace Elements}

Limited attempts have been made for classifying trace elements solely. The classifications which address the presence of trace elements have been listed. 
2.1. WHO Classification, 1973 [6]. As per this classification, nineteen trace elements have been divided into three groups:

(1) Essential elements: zinc $(\mathrm{Zn})$, copper $(\mathrm{Cu})$, selenium $(\mathrm{Se})$, chromium $(\mathrm{Cr})$, cobalt $(\mathrm{Co})$, iodine (I), manganese $(\mathrm{Mn})$, and molybdenum (Mo).

(2) Probably essential elements.

(3) Potentially toxic elements.

2.2. Frieden's Classification of Elements. In 1981, Frieden proposed a biological classification of trace elements based on their amount in tissues [7]:

(1) Essential trace elements: boron, cobalt, copper, iodine, iron, manganese, molybdenum, and zinc.

(2) Probably essential trace elements: chromium, fluorine, nickel, selenium, and vanadium.

(3) Physically promotive trace elements: bromine, lithium, silicon, tin, and titanium.

2.3. Frieden's Categorical Classification of Elements [8]. Twenty-nine types of elements present in the human body have been classified into five major groups as follows:

(i) Group I: basic components of macromolecules such as carbohydrates, proteins, and lipids. Examples include carbon, hydrogen, oxygen, and nitrogen.

(ii) Group II: nutritionally important minerals also referred to as principal or macroelements. The daily requirement of these macroelements for an adult person is above $100 \mathrm{mg} /$ day. Examples include sodium, potassium, chloride, calcium, phosphorous, magnesium, and sulfur.

(iii) Group III: essential trace elements. The trace elements are also called minor elements. An element is considered a trace element when its requirement per day is below $100 \mathrm{mg}$. The deficiency of these elements is rare but may prove fatal. Examples include copper, iron, zinc, chromium, cobalt, iodine, molybdenum, and selenium.

(iv) Group IV: additional trace elements. Their role is yet unclear and they may be essential. Examples include cadmium, nickel, silica, tin, vanadium, and aluminum. This group may be equivalent to probably essential trace elements in the WHO classification.

(v) Group V: these metals are not essential and their functions are not known. They may produce toxicity in excess amounts. Examples include gold, mercury, and lead. This group is equivalent to potentially toxic elements defined in the WHO classification.

\section{Discussion}

An extensive and complex system is functioning inside the human body to manage and maintain the amount of essential trace elements within a normal range. Micronutrients from diet are transported into the blood if there is deficiency, enter cells if cellular levels are not adequate, or are excreted if blood and cell levels are satisfactory or elevated. Various essential trace elements along with nutritional requirement and dietary sources have been listed in Table 1.

3.1. Copper. Copper is the third most abundant trace element with only $75-100 \mathrm{mg}$ of total amount in the human body [9]. Copper is present in almost every tissue of the body and is stored chiefly in the liver along with the brain, heart, kidney, and muscles [10]. Copper is absorbed in the gut and transported to the liver. In human blood, copper is principally distributed between the erythrocytes and in the plasma [11]. It is transported in the form of ceruloplasmin into the plasma where its metabolism is controlled and is excreted in bile [12]. Ceruloplasmin accounts for $90 \%$ of the copper content in blood and is responsible for carrying copper to the deficient cells [13]. Copper-zinc metalloenzyme superoxide dismutase contains $60 \%$ of the copper in erythrocytes and the remaining $40 \%$ is loosely bound to other proteins and amino acids.

3.1.1. Biological Functions. A significant number of metabolic enzymes function properly due to copper [13-16]. The biological functions of copper have been listed [14-16]:

(1) The enzyme cytochrome c oxidase, comprising copper and iron, plays a vital role in energy production during aerobic respiration.

(2) Copper is also present in superoxide dismutase which detoxifies superoxides by converting them to oxygen and hydrogen peroxide.

(3) Copper is also a component of lysyl oxidase which takes part in the synthesis of collagen and elastin. Copper is also essential for maintaining the strength of the skin, hair, blood vessels, and epithelial and connective tissue throughout the body.

(4) $\mathrm{Cu}$ plays a considerable role in the production of hemoglobin. Ceruloplasmin catalyzes the oxidation of iron which subsequently is necessary to bind to its transport protein, transferrin [12].

(5) Melanin production: copper containing enzyme tyrosinase converts tyrosine to melanin.

(6) Myelin production: $\mathrm{Cu}$ is also necessary for the synthesis of phospholipids found in myelin sheaths in peripheral nerves $[13,16]$.

(7) Copper is also required for the production of the thyroid hormone thyroxine [13].

(8) Copper can act as both an antioxidant and a prooxidant. As an antioxidant, $\mathrm{Cu}$ scavenges or neutralizes free radicals and may reduce or help prevent some of the damage they cause [16-19]. Copper promotes free radical damage to the tissues when it acts as prooxidant [20].

3.1.2. Role in Oral Health and Diseases. The symptoms of copper deficiency are hypochromic anemia, neutropenia, 
TABLE 1: Showing trace elements, their RDI, RDA, and UL in the body, and rich dietary sources $[64,66,83]$.

\begin{tabular}{|c|c|c|c|c|}
\hline Trace element & $\begin{array}{l}\text { Recommended } \\
\text { daily intake } \\
\text { (RDI) }\end{array}$ & $\begin{array}{l}\text { Recommended dietary allowance } \\
\text { (RDA) }\end{array}$ & Tolerable upper intake level (UL) & Dietary sources \\
\hline Copper & $2000 \mu \mathrm{g}$ & $\begin{array}{l}\text { Children } 1 \text { to } 3 \text { years old: } \\
340 \mathrm{mcg} / \text { day; } 4 \text { to } 8 \text { years old: } \\
440 \mathrm{mcg} / \text { day; } 9 \text { to } 13 \text { years old: } \\
700 \mathrm{mcg} / \text { day; } 14 \text { to } 18 \text { years old: } \\
890 \mathrm{mcg} / \text { day } \\
\text { Men and women aged } 19 \text { years and } \\
\text { older: } 900 \mathrm{mcg} / \text { day } \\
\text { Pregnancy: } 1000 \mathrm{mcg} / \mathrm{day} \\
\text { Lactation: } 1300 \mathrm{mcg} / \text { day }\end{array}$ & $\begin{array}{l}\text { Children } 1 \text { to } 3 \text { years old: } 1 \mathrm{mg} / \text { day; } \\
4 \text { to } 8 \text { years old: } 3 \mathrm{mg} / \text { day; } 9 \text { to } 13 \\
\text { years old: } 5 \mathrm{mg} / \text { day; } 14 \text { to } 18 \text { years } \\
\text { old: } 8 \mathrm{mg} / \text { day } \\
\text { Adults } 19 \text { years old and above } \\
\text { (including lactation): } 10 \mathrm{mg} / \text { day } \\
\text { Pregnancy: } 8 \mathrm{mg} / \text { day }\end{array}$ & $\begin{array}{l}\text { Oysters, other shell fish, } \\
\text { whole grains, beans, } \\
\text { nuts, potatoes, organ } \\
\text { meats (kidney, liver), } \\
\text { dark leafy greens, dried } \\
\text { fruits, and yeast }\end{array}$ \\
\hline Iron & $18 \mathrm{mg}$ & $\begin{array}{l}\text { Children } 1 \text { to } 3 \text { years old: } 7 \mathrm{mg} / \text { day; } \\
4 \text { to } 8 \text { years old: } 10 \mathrm{mg} / \text { day; } 9 \text { to } 13 \\
\text { years old: } 8 \mathrm{mg} / \text { day } \\
\text { Boys } 14 \text { to } 18 \text { years old: } \\
11 \mathrm{mg} / \text { day } \\
\text { Girls } 14 \text { to } 18 \text { years old: } 15 \mathrm{mg} / \text { day } \\
\text { Adults: } 8 \mathrm{mg} / \text { day for men aged } 19 \\
\text { and older and women aged } 51 \text { and } \\
\text { older } \\
\text { Women } 19 \text { to } 50 \text { years old: } \\
18 \mathrm{mg} / \text { day } \\
\text { Pregnant women: } 27 \mathrm{mg} / \text { day } \\
\text { Lactating mothers: } 10 \mathrm{mg} / \text { day }\end{array}$ & $\begin{array}{l}\text { Infants and children from birth to } \\
\text { the age of 13: } 40 \mathrm{mg} / \text { day } \\
\text { Children aged } 14 \text { and adults } \\
\text { (including pregnancy and } \\
\text { lactation): } 45 \mathrm{mg} / \text { day }\end{array}$ & $\begin{array}{l}\text { Haem iron: liver, meat, } \\
\text { poultry, and fish } \\
\text { Nonhaem iron: cereals, } \\
\text { green leafy vegetables, } \\
\text { legumes, nuts, oilseeds, } \\
\text { jaggery, and dried fruits }\end{array}$ \\
\hline Zinc & $15 \mathrm{mg}$ & $\begin{array}{l}\text { Infants and children } 7 \text { months old } \\
\text { to } 3 \text { years old: } 3 \mathrm{mg} / \text { day; } 4 \text { to } 8 \text { years } \\
\text { old: } 5 \mathrm{mg} / \text { day; } 9 \text { to } 13 \text { years old: } \\
8 \mathrm{mg} / \text { day } \\
\text { Girls } 14 \text { to } 18 \text { years old: } 9 \mathrm{mg} / \text { day } \\
\text { Boys and men aged } 14 \text { and older: } \\
11 \mathrm{mg} / \text { day } \\
\text { Women } 19 \text { years old and above: } \\
8 \mathrm{mg} / \text { day } \\
\text { Pregnant women: } 11 \mathrm{mg} / \text { day } \\
\text { Lactating women: } 12 \mathrm{mg} / \text { day }\end{array}$ & $\begin{array}{l}\text { Infants: } 4-5 \mathrm{mg} / \text { day } \\
\text { Children } 1 \text { to } 3 \text { years old: } 7 \mathrm{mg} / \text { day; } \\
4 \text { to } 8 \text { years old: } 12 \mathrm{mg} / \text { day; } 9 \text { to } 13 \\
\text { years old: } 23 \mathrm{mg} / \text { day; } 14 \text { to } 18 \text { years } \\
\text { old: } 34 \mathrm{mg} / \text { day } \\
\text { Adults } 19 \text { years old and above } \\
\text { (including pregnancy and } \\
\text { lactation): } 40 \mathrm{mg} / \text { day }\end{array}$ & $\begin{array}{l}\text { Animal food: meat, } \\
\text { milk, and fish } \\
\text { Bioavailability of zinc in } \\
\text { vegetable food is low }\end{array}$ \\
\hline Cobalt & $6 \mu \mathrm{g}$ & $\begin{array}{l}\text { Infants: } 0.5 \text { mcg } \\
\text { Children } 1-3 \text { years old: } 0.9 \text { mcg; } 4-8 \\
\text { years old: } 1.2 \text { mcg; } 9-13 \text { years old: } \\
1.8 \text { mcg } \\
\text { Older children and adults: } 2.4 \text { mcg } \\
\text { Pregnant women: } 2.6 \mathrm{mcg} \\
\text { Lactating mothers: } 2.8 \mathrm{mcg}\end{array}$ & Not known & $\begin{array}{l}\text { Fish, nuts, green leafy } \\
\text { vegetables (broccoli, } \\
\text { spinach), cereals, and } \\
\text { oats }\end{array}$ \\
\hline Chromium & $120 \mu \mathrm{g}$ & $\begin{array}{l}\text { Children } 1 \text { to } 3 \text { years old: } 11 \mathrm{mcg} ; 4 \\
\text { to } 8 \text { years old: } 15 \text { mcg } \\
\text { Boys } 9 \text { to } 13 \text { years old: } 25 \mathrm{mcg} \\
\text { Men } 14 \text { to } 50 \text { years old: } 35 \mathrm{mcg} \\
\text { Men } 51 \text { years old and above: } 30 \mathrm{mcg} \\
\text { Girls } 9 \text { to } 13 \text { years old: } 21 \mathrm{mcg} ; 14 \text { to } \\
18 \text { years old: } 24 \text { mcg } \\
\text { Women } 19 \text { to } 50 \text { years old: } 25 \mathrm{mcg} \text {; } \\
51 \text { years old and above: } 20 \mathrm{mcg} \\
\text { Pregnant women: } 30 \mathrm{mcg} \\
\text { Lactating women: } 45 \mathrm{mcg}\end{array}$ & Doses larger than $200 \mathrm{mcg}$ are toxic & $\begin{array}{l}\text { Best sources: processed } \\
\text { meats, whole grains, and } \\
\text { spices }\end{array}$ \\
\hline Molybdenum & $75 \mu \mathrm{g}$ & $\begin{array}{l}\text { Children } 1 \text { to } 3 \text { years old: } \\
17 \mathrm{mcg} / \text { day; } 4 \text { to } 8 \text { years old: } \\
22 \mathrm{mcg} / \text { day; } 9 \text { to } 13 \text { years old: } \\
34 \mathrm{mcg} / \text { day; } 14 \text { to } 18 \text { years old: } \\
43 \mathrm{mcg} / \text { day } \\
\text { Men and women aged } 19 \text { years and } \\
\text { above: } 45 \mathrm{mcg} / \text { day } \\
\text { Pregnancy and lactation: } \\
50 \mathrm{mcg} / \text { day }\end{array}$ & $\begin{array}{l}\text { Children: } 300-600 \mathrm{mcg} / \mathrm{day} \\
\text { Adults (including pregnancy and } \\
\text { lactation): } 1100-2000 \mathrm{mcg} / \text { day }\end{array}$ & $\begin{array}{l}\text { Animal food: liver; } \\
\text { vegetables: lentils, dried } \\
\text { peas, kidney beans, } \\
\text { soybeans, oats, and } \\
\text { barley }\end{array}$ \\
\hline
\end{tabular}


TABLE 1: Continued.

\begin{tabular}{|c|c|c|c|c|}
\hline Trace element & $\begin{array}{l}\text { Recommended } \\
\text { daily intake } \\
\text { (RDI) }\end{array}$ & $\begin{array}{l}\text { Recommended dietary allowance } \\
\text { (RDA) }\end{array}$ & Tolerable upper intake level (UL) & Dietary sources \\
\hline Selenium & $70 \mu \mathrm{g}$ & $\begin{array}{l}\text { Children } 1-3 \text { years old: } 20 \\
\text { micrograms/day } \\
\text { Children } 4-8 \text { years old: } 30 \\
\text { micrograms/day } \\
\text { Children } 9-13 \text { years old: } 40 \\
\text { micrograms/day } \\
\text { Adults and children } 14 \text { years old and } \\
\text { above: } 55 \text { micrograms/day } \\
\text { Pregnant women: } 60 \\
\text { micrograms/day } \\
\text { Breastfeeding women: } 70 \\
\text { micrograms/day }\end{array}$ & $\begin{array}{l}\text { The safe upper limit for selenium is } \\
400 \text { micrograms a day in adults }\end{array}$ & $\begin{array}{l}\text { Liver, kidney, seafood, } \\
\text { muscle meat, cereal, } \\
\text { cereal products, dairy } \\
\text { products, fruits, and } \\
\text { vegetables }\end{array}$ \\
\hline Iodine & $150 \mu \mathrm{g}$ & $\begin{array}{l}\text { Children } 1 \text { to } 8 \text { years old: } \\
90 \mathrm{mcg} / \text { day; } 9 \text { to } 13 \text { years old: } \\
120 \mathrm{mcg} / \text { day } \\
\text { Children aged } 14 \text { and adults: } \\
150 \mathrm{mcg} / \text { day } \\
\text { Pregnant women: } 209 \mathrm{mcg} / \text { day } \\
\text { Lactating mothers: } 290 \mathrm{mcg} / \text { day }\end{array}$ & $\begin{array}{l}\text { Children } 1 \text { to } 3 \text { years old: } \\
200 \mathrm{mcg} / \text { day; } 4 \text { to } 8 \text { years old: } \\
300 \mathrm{mcg} / \text { day; } 9 \text { to } 13 \text { years old: } \\
600 \mathrm{mcg} / \text { day; } 14 \text { to } 18 \text { years old: } \\
900 \mathrm{mcg} / \text { day } \\
\text { Adults above the age of } 19 \text { including } \\
\text { pregnant and breastfeeding women: } \\
1100 \mathrm{mcg} / \text { day }\end{array}$ & $\begin{array}{l}\text { Best sources: seafoods } \\
\text { (sea fish and sea salt) } \\
\text { and cod liver oil } \\
\text { Small amounts: milk, } \\
\text { vegetables, and cereals }\end{array}$ \\
\hline Fluorine & $\begin{array}{l}\text { In drinking } \\
\text { water: } 0.5 \text { to } \\
0.8 \mathrm{mg}\end{array}$ & $\begin{array}{l}\text { Children } 1 \text { through } 3 \text { years old: } \\
0.7 \text { mg; } 4 \text { to } 8 \text { years old: } 1 \mathrm{mg} ; 9 \text { to } 13 \\
\text { years old: } 2 \text { mg; } 14 \text { to } 18 \text { years old: } \\
3 \mathrm{mg} \\
\text { Men } 19 \text { years old and above: } 4 \mathrm{mg} \\
\text { Women } 14 \text { years old and above } \\
\text { (including pregnant or } \\
\text { breastfeeding women): } 3 \mathrm{mg}\end{array}$ & $\begin{array}{l}0.7-9 \mathrm{mg} \text { for infants } \\
1.3 \mathrm{mg} \text { for children } 1 \text { to } 3 \text { years of age } \\
2.2 \mathrm{mg} \text { for children } 4 \text { to } 8 \text { years of } \\
\text { age } \\
10 \mathrm{mg} \text { for children above } 8 \text { years old, } \\
\text { adults, and pregnant and } \\
\text { breastfeeding women }\end{array}$ & $\begin{array}{l}\text { Drinking water, foods } \\
\text { (sea fish and cheese), } \\
\text { and tea }\end{array}$ \\
\hline
\end{tabular}

hypopigmentation of hair and skin, abnormal bone formation with skeletal fragility and osteoporosis, joint pain, lowered immunity, vascular aberrations, and kinky hair [21]:

(1) Deficiency of $\mathrm{Cu}$ in diet for a prolonged period especially during stages of active growth leads to anemia and defective keratinisation in the oral cavity [22]. The anemic effect is attributed to decreased ferroxidase activity of ceruloplasmin and reduced iron oxidation [5].

(2) Infections: lowered immunity can result in various infections of the oral cavity due to accompanied neutropenia [23]. Granulocyte maturation disorder in the bone marrow and vacuolation in neutrophils have been noted [5].

(3) Bone abnormalities and pain: bone changes in copper deficiency include a loss of trabecular formation with thinning of the cortex. There may be osteoporosis and occipital horn formation due to functional impairment of copper-requiring enzymes such as ascorbate oxidase and lysyl oxidase in case of copper deficiency [10].

(4) Oral lesions: various studies found that the mean serum copper levels were significantly higher in the sera of patients with oral potentially malignant disorders such as oral leukoplakia and oral submucous fibrosis and also malignant tumors such as squamous cell carcinoma. The average intake of copper in India is $2.1-3.9 \mathrm{mg} /$ day whereas, due to areca nut chewing, it is more than $5 \mathrm{mg} /$ day. It has been postulated that copper released from areca nuts while chewing came in direct contact with the oral epithelium and is dissolved in the saliva. Copper is reportedly present in the saliva for as long as 30 minutes. The longer the presence of copper in saliva, the higher the chances of its uptake by the oral epithelium [24]. It has been advocated that copper appears in the blood after 15 mins of ingestion of areca nut and its products [25]. In oral submucous fibrosis patients, the serum levels of $\mathrm{Cu}$ gradually increase as the clinical stage of the disease progresses. However, local effect of raised salivary copper may have a more important role to play than the raised serum levels. Other schools of thoughts appraised decrease in the copper serum concentrations due to usage of copper in upregulation of lysyl oxidase leading to excessive cross linkage of collagen [26].

(5) $\mathrm{Cu}$ is also believed to possess caries promoting property [27].

3.2. Zinc. There is $2-4$ grams of $\mathrm{Zn}$ distributed throughout the human body [28]. Zinc is stored in prostate, parts of 
the eye, brain, muscle, bones, kidney, and liver [29]. It is the second most abundant transition metal in organisms after iron and it is the only metal which appears in all enzyme classes $[28,30]$. In blood plasma, $\mathrm{Zn}$ is bound to and transported by albumin (60\%) and transferrin (10\%) [31]. Since transferrin also transports iron, excessive iron can reduce zinc absorption, and vice versa [32]. The concentration of zinc in blood plasma stays relatively constant regardless of zinc intake.

3.2.1. Biological Functions. Zinc functions in biology are numerous but can be separated into three main categories: catalytic, regulatory, and structural roles. It is required for the catalytic activity of a large number of enzymes [33, 34]. It plays an important role in immune function, wound healing, protein synthesis, DNA synthesis, and cell division [34-36]. Zinc is required for proper sense of taste and smell [37, 38]. It also supports normal growth and development during pregnancy, childhood, and adolescence [39-42]. Allegedly, it also possesses antioxidant properties and thus may play a role in speeding up the healing process after an injury and protecting against accelerated aging [40,43]. Zinc ions are effective antimicrobial agents even at low concentrations.

3.2.2. Role in Oral Health and Diseases. The roles of zinc in oral health and diseases are summarized as follows:

(1) In the oral cavity, zinc is present naturally in plaque, saliva, and enamel. Zinc is transformed into oral health products to control plaque, reduce malodor, and retard calculus formation. The zinc elevated concentrations can be sustained for prolonged periods in plaque and saliva following delivery from mouthrinses and toothpastes. Although low concentrations of zinc can both reduce enamel demineralisation and modify remineralisation, the anticariogenic efficacy is yet disputable and not supported by various researches [44].

(2) Taste disorders: the role of zinc in taste functions is appreciable at various levels of organization such as taste buds, the taste sense nerve transmission, and brain. Zinc plays an important role in cell structure architecture, maintaining the cell membrane integrity, and functions of various cytoplasmic and membrane enzymes. Early researchers concluded that zinc deficiency secondary to any etiology leads to taste disturbances and thus still zinc depletion is corrected for patients reporting with taste imbalances [45].

(3) A study conducted on rodents concluded that zincdeficient diet can result in parakeratosis of normally orthokeratinized oral mucosa. Hence, zinc deficiency can be a potential risk factor for oral and periodontal diseases. The parakeratotic changes in cheek, tongue, and esophagus are a sign of zinc deficiency. Thickening of the buccal mucosa is a common manifestation along with loss of filiform papillae [46].

(4) As stated above, zinc is a cofactor for superoxide dismutase enzyme and various studies have shown lower levels of serum zinc in patients with potentially premalignant disorders like oral leukoplakia. This may be due to consumption of zinc in counter reaction to high content of copper in areca nut or oxidants released during tobacco usage [47].

(5) Similarly, concentration of zinc in serum is significantly decreased in oral squamous cell carcinoma and oral submucous fibrosis patients with history of tobacco consumption when compared to the control group and gradually decreased with the duration of the habit. The serum level of zinc was reportedly lower in oral squamous cell carcinoma patients than in oral submucous fibrosis patients $[25,48]$.

(6) As transferrin transports both iron and zinc, the level of zinc increases as the level of iron decreases in iron deficiency patients. Thus, patients of OSMF also suffering from iron deficiency anemia show higher serum levels of zinc $[25,48]$.

(7) Superoxide dismutase which is a natural antioxidant of the body is a $\mathrm{Cu}-\mathrm{Zn}$ protein complex that has an anticarcinogenic effect in OSMF. Secondly, zinc decreases the activity of copper containing lysyl oxidase enzyme and thus causes inhibition of cross linkage of collagen peptides. It also plays a significant role in promoting collagen degradation through collagenase and matrix metalloproteinase. Zinc thus bears an inverse relationship with copper and thereby interferes with the mucosal absorption of copper. Excess zinc particularly impairs copper absorption as both metals are absorbed through metallothioneins. The ratio of copper to zinc is also believed to be a reliable biomarker in the development and progression towards carcinogenesis [48].

(8) On the contrary to the popular belief of protective function of zinc, limited literature suggests carcinogenic effect of zinc [49].

3.3. Iron. Iron is the most abundant essential trace element in the human body. The total content of iron in the body is about 3-5g with most of it in the blood and the rest in the liver, bone marrow, and muscles in the form of heme [50]. Iron is absorbed in the gut from diet in case of depletion and transported in the form of ferritin. Hemosiderin is a golden brown pigment which is a byproduct of metabolism of ferritin and is deposited in the cells of the reticuloendothelial system [51]. Homeostasis of iron maintains the iron levels in serum within normal range only by upregulation or downregulation of absorption mechanism of iron which is unique because it maintains homeostasis by regulating the absorption and never excretion.

3.3.1. Biological Functions. Heme is the major iron containing substance in ferrous or ferric state which is present in hemoglobin, myoglobin, and cytochrome. There are numerous enzymes associated with iron, namely, cytochrome ac, p450, cytochrome c reductase, catalases, peroxidases, 
xanthine oxidases, tryptophan pyrrolase, succinate dehydrogenase, glucose-6-phosphate dehydrogenase, and choline dehydrogenase. Heme forms covalent bonds with the globin protein to form hemoglobin which is the major oxygen carrying pigment in RBCs of mammalians. It takes part in a myriad of metabolic cycles such as in the energy producing reactions (the cytochromes of the Krebs cycle) in all the cells and activates the energy producing oxidizing enzymes. Apart from participation in maintaining innumerable physiological and metabolic processes, it is also necessary for DNA, RNA, collagen, antibody synthesis, and so forth [52]. The biological roles of iron in the human body are beyond the scope of this paper and only few important ones have been listed.

3.3.2. Role in Oral Health and Diseases. The roles of iron in oral health and diseases are summarized as follows:

(1) Iron deficiency anemia is the most common manifestation of low serum levels of this important trace element. Microcytic hypochromic RBCs, fatigue, achlorhydria, atrophy of epithelium, loss of attention, irritability, dyspnea, and lowered memory are some of the features of iron deficiency anemia [25]. The oral manifestations of iron deficiency anemia can be summarized as angular cheilitis, atrophic glossitis, generalised oral mucosal atrophy, candidal infections, pallor, and stomatitis. Plummer-Vinson syndrome or Paterson-Kelly syndrome or sideropenic dysphagia is a rare condition characterized by iron deficiency anemia, dysphagia, and koilonychia with women being affected more than men. Dysphagia results from the presence of abnormal esophageal webs which have predisposition towards malignant transformation [53].

(2) Oral premalignant lesions and conditions: a significant decrease in serum iron concentrations with elevated total iron-binding capacity has been found in OSMF patients. The decreased iron levels in OSMF patients might be due to utilization of iron in collagen synthesis. In addition, deficient iron in the oral tissues results in decreased vascularity which further facilitates percolation of arecoline (byproduct of areca nut). Further damage is caused by increased arecoline percolation which enhances fibroblastic proliferation and collagen formation [25]. Though majority of the literature suggests that OSMF leads to iron deficiency due to impaired dietary habits, Bhattacharya et al. reported an interesting case where iron deficiency anemia primarily resulted in development of oral submucous fibrosis which was successfully treated by oral administration of iron supplements and antioxidants [54]. Similarly, low serum levels of iron have been assessed in patients suffering from oral leukoplakia.

(3) It has also been noted that serum ferritin levels are elevated and serum iron concentrations are decreased with tumor progression in head and neck carcinomas and thus heme can be used as a follow-up tool for patients along with nutritional assessment [47].
3.4. Cobalt. The presence of cobalt in animal tissues was first established by Bertrand and Macheboeuf in 1925 which was later confirmed by various researches using spectrographic methods $[55,56]$. Cobalt is an essential trace element for the human body and can occur in organic and inorganic forms. In organic form, it forms an integral part of vitamin B12 and has a substantial role in the formation of amino acids and neurotransmitters. Inorganic forms of cobalt are toxic to the human body, and the longer they stay in the body, the more the detrimental effects they cause in cells. Cobalt ions are absorbed within the human body through several pathways: firstly, with food; secondly, by the respiratory system; thirdly, by the skin; and finally, as a component of biomaterials. The cobalt ions enter the body through any of the abovementioned routes and bind with proteins within the bloodstream and get transported with blood to be deposited in tissues and cells. The total body content of cobalt has been estimated between 80 and 300 mcg of vitamin B12 [57-59].

3.4.1. Biological Functions. Vitamin B12, also known as cobalamin, is a water soluble vitamin and contains the biochemically rare element cobalt in the center of a planar tetrapyrrole corrin ring. Vitamin B12 is produced as hydroxocobalamin within bacteria and conversion to methylcobalamin and $5^{\prime}$-deoxyadenosylcobalamin, enzymatically active cofactor forms, occurs within the body. Cyanocobalamin, the fourth vitamer of vitamin B12, can be metabolized in the body to an active coenzyme form and used in food supplements. Erythropoietin, essential for formation of erythrocytes, stimulation is performed by vitamin B12 containing cobalt salts, and thus the deficiency of cobalt is strongly related to disturbances in vitamin B12 synthesis resulting in anemia and hypofunction of thyroid with increased risk of developmental abnormalities and failure in infants [59]. Apart from being an important constituent of these various forms of vitamin B12, the presence of cobalt is necessary for the efficient formation of amino acids and various proteins for myelin sheath generation. Cobalt also plays a decisive role in generating neurotransmitters, which are requisite for proper operation of an organism. On the other hand, excess of cobalt ions within the body might increase the action of thyroid and bone marrow resulting in overproduction of erythrocytes, fibrosis in lungs, and asthma [60].

3.4.2. Role in Oral Health. The roles of cobalt in oral health are summarized as follows:

(1) Cobalt, part of vitamin B12 also referred to as extrinsic factor, is essential for formation of erythrocytes. Thus, the most well-known manifestation of cobalt deficiency in oral cavity is pernicious anemia which is characterized by glossitis, burning sensation, beefy red tongue present in the form of patches or completely red tongue which is also referred to as Hunters' or Moeller's glossitis, and rarely shallow ulcers [61].

(2) Apart from erythropoiesis, vitamin B12 also plays a significant role in nerve repair and regeneration. Hence, deficiency of cobalt can have adverse effects such as peripheral neuropathy. 
(3) Lichen planus and oral lichenoid reactions have been linked to their exposure to $\mathrm{Cr}, \mathrm{Co}, \mathrm{Ni}$, and amalgam alloys that are released from metal alloys commonly used in dentistry in the oral cavity. These trace metals when released from the metal alloys come into direct contact with oral mucosa, leading to immune mediated damage of basal epithelial keratinocytes and subsequently inducing sensitivity reactions in the form of OLR. Some studies have linked OLR to risk of malignant transformation [62].

3.5. Chromium. The word "chrome" is a Greek word which means "color." Chromium exists in divalent [ $\mathrm{Cr}(\mathrm{II})]$, trivalent [Cr(III)], and hexavalent $[\mathrm{Cr}(\mathrm{VI})]$ oxidation states, with $\mathrm{Cr}(\mathrm{VI})$ and $\mathrm{Cr}$ (III) being the most stable forms, among which $\mathrm{Cr}$ (III) and $\mathrm{Cr}(\mathrm{VI})$ are insoluble and soluble forms, respectively. The total body content of chromium is relatively low and is about $0.006 \mathrm{~g}$ in an average healthy human adult. Trivalent $\mathrm{Cr}$ is an essential trace element and plays an important role in glucose metabolism by serving as a cofactor for insulin action. Hexavalent chromium is a toxic industrial pollutant and has been classified as carcinogen possessing mutagenic and teratogenic properties. Chromium exposure through occupation via inhalation has been associated with various lung, GIT, and central nervous system cancers. Chromium is excreted principally in the urine and faeces and in small quantities in the hair, sweat, and bile [63].

3.5.1. Biological Functions. Chromium is an important trace element for overweight people as it is one of the key minerals in controlling blood sugar and lipid levels. Chromium [Cr(III)] increases the efficacy of insulin and stimulating glucose uptake from the muscles and other tissues being the main ingredient of glucose tolerance factor (GFT). In case of low serum levels of chromium, the circulating level of (GFT) is also less, and, consequently, insulin is less effective in reducing blood sugar. As a result, high blood sugar stimulates further release of ineffective insulin $[64,65]$. Chromium is thought to repress p53, a tumor suppressor protein, whose inactivation through mutations is associated with many types of human cancers. Chrome ulcers, corrosive reactions on the nasal septum, acute irritation dermatitis, and allergic eczematous dermatitis have been reported among individuals exposed to hexavalent chromium compounds. Industrial workers exposed to chromates have been documented to be at excessive risk of lung cancer.

As chromium is present in very low amounts in the body, it is difficult to ascertain the deficient state. It is believed that if concentrations of chromium are lower than the normal value of $0.14-0.15 \mathrm{ng} / \mathrm{mL}$ in serum, this will indicate the presence of a severe chromium deficiency. In spite of that, elevated plasma levels can coexist with a negative tissue balance. Hyperglycemia may be concomitant with raised plasma chromium and increased urinary excretion. The concentrations of chromium in urine, hair, and body fluids could not reflect the true chromium status of the body [65].
3.5.2. Role in Oral Health and Diseases. The role of chromium in OLR has been discussed earlier [62]. Hyperglycemic status of diabetic patients in undiagnosed chromium deficient state may lead to a wide spectrum of oral manifestations noted in diabetics such as delayed wound healing, suppurative periodontitis, various oral fungal infections, premature periodontal diseases, and hyposalivation [66].

3.6. Selenium. Selenium is a vital trace element which is an important component of the antioxidant enzymes such as glutathione peroxides and thioredoxin reductase [67]. The selenium salts required for various cellular functions inside the human body are toxic in excess amounts. Microorganisms reportedly have several selenium containing enzymes, and it is most likely that selenoproteins other than glutathione peroxidase remain to be discovered in higher animals. Historically, endemic in children aged 2-10 years and in women of childbearing age, Keshan disease had a geographic distribution along wide belt-like region throughout mainland China, from northeast to southwest. Typical manifestations were fatigue after even mild exercise, cardiac arrhythmia and palpitations, loss of appetite, cardiac insufficiency, cardiomegaly, and congestive heart failure. The disease was prevalent among people under selenium deficient diet and the patients improved rapidly on fortification. Similarly, selenium-responsive bone and joint disease, Kashin-Beck disease, has also been detected in children aged 5-13 years in China and less so in southeast Siberia. Kashin-Beck disease also occurs in areas with low levels of selenium in cultivation soil.

3.6.1. Biological Functions. Selenium is known to possess immunomodulating and antiproliferative properties and may effect immune response by altering the expression of cytokines and their receptors or making immune cells more resistant to oxidative stress $[68,69]$. As a part of enzyme glutathione peroxidase along with vitamin E, catalase, and superoxide dismutase, selenium forms component of one of the imperative antioxidant defence systems of the body. There is also compelling evidence that an unknown selenoenzyme protein has some role in the synthesis of the triiodothyronine hormone from thyroxine [70, 71].

3.6.2. Role in Oral Health and Diseases. The serum levels of selenium showed progressive reduction from healthy subjects to patients having premalignant lesions like oral leukoplakia and further decrease in patients suffering from oral cancer. There was a reduction in the selenium containing glutathione peroxidase levels as well and there was a concomitant increase in the oxidative stress in the same order [72].

Hence, it is clearly evident that decrease in the concentrations of selenium will result in increased oxidative stress inside the body tissues with inadvertent harmful effects. Thus, nutritional supplementation with trace elements such as selenium is an important rationale in the treatment of premalignant lesions like leukoplakia, conditions as OSMF, and oral cancer patients to reduce oxidative stress inside the body [54]. 
A recent study evaluated the anti-inflammatory and antioxidant effect of selenium by administration in patients suffering from oral mucositis secondary to high dose chemotherapy. The researchers maintained that adequate supplementation of selenium could produce cytoprotective effects and antiulcer activity and concluded that selenium can effectively reduce the duration and severity of oral mucositis in these patients [73].

3.7. Molybdenum. Molybdenum minerals have been known throughout history, but the element was discovered by Carl Wilhelm Scheele in 1778 and first isolated in 1781 by Peter Jacob Hjelm.

3.7.1. Biological Functions. Molybdenum, as a component of molybdoprotein, takes part in the formation of active sites for various enzymes. The three principal molybdenumcontaining enzymes are xanthine dehydrogenase/oxidase, aldehyde oxidase, and sulphite oxidase. A molybdenumcontaining enzyme has some role to play in purine catabolism. It also influences protein synthesis and growth of the body [74]. Molybdenum has an antagonistic effect against copper; thus, high concentrations of molybdenum can reduce copper absorption and subsequently lead to copper deficiency [75].

3.7.2. Role in Oral Health and Diseases. Boron, vanadium, and molybdenum are believed to possess a cariostatic effect. Various researches from Hungary and New Zealand strongly suggested molybdenum-flouride interaction to have a strong cariostatic effect. However, the cariostatic effect of molybdenum has been critically reviewed in the literature with inconclusive results. Nonetheless, teeth enamel accrues considerable amounts of molybdenum. Further researches or investigations are warranted to derive reliable observations [76].

3.8. Fluorine. Fluorine makes negligible part of body weight and enters the system principally through drinking water and to a lesser extent through foods.

3.8.1. Biological Functions. Fluorine, in the form of fluorapatite crystals, is an important part of the organized matrix of hard tissues like bone and teeth. It is also believed that fluoride, in combination with calcium, stimulates osteoblastic activity [64].

3.8.2. Role in Oral Health and Diseases. Low levels of fluoride in drinking water have been associated with dental decay. The excessive concentrations of fluoride during calcification stage of the teeth can result in a kind of enamel hypoplasia termed dental fluorosis. Clinically, dental fluorosis can vary from small white opacities in the enamel to severe mottling of the tooth structure with increasing severity. The overall effect of excessive fluoride intake on the dental structure depends on many factors such as concentration of fluoride in drinking water, stage of calcification of teeth when exposure occurred, duration of exposure, and amount of exposure [61].
3.9. Iodine. Iodine is a vital trace element required at all stages of life especially during formative years. It is important to sustain the daily functions of human body and deficiency or excess can have significant adverse effects on the body.

3.9.1. Biological Functions. Iodine is an essential component of thyroid hormones, that is, tetraiodothyronine (T4 or thyroxine) and triiodothyronine (T3). It plays a significant role in the functioning of the parathyroid glands. Iodine plays an important role in general growth and development of the body along with maintaining metabolic processes [64].

3.9.2. Role in Oral Health and Diseases. There can be innumerable symptoms of iodine deficiency or excess. The deficiency of iodine is more commonly evident. Most commonly reported symptoms of iodine deficiency are extreme fatigue, irritability, mental disturbances, weight gain, facial puffiness, constipation, and lethargy. Untreated infants have the risk of developing cretinism and end up suffering from poor growth and mental retardation [64].

It has also been hypothesized that dietary deficiency or excess of iodine plays an imperative role in oral mucosa and in salivary glands physiology. Salivary glands can protect their own cells from peroxidation due to iodine concentrating ability through sodium iodide symporter and peroxidase activity. Iodide seems to have a primitive antioxidant function in iodide concentrating organisms. Significant role of iodine in oral immune defense mechanism may be substantiated by high concentration of iodine in thymus. S. Venturi and M. Venturi also suggested that these actions of iodides might be important for prevention of various oral and salivary glands diseases [77].

It was also evident in a study conducted by Littleton and Frohlich in 1993 that the skeletal remains from iodine rich zones of the world showed greater attrition, lesser dental caries, and reduced premature teeth loss. Early loss of teeth can be a primary factor in undernutrition and loss of health and compromised quality of life [78].

Deficiency of iodine is not uncommon in various parts of the world population. Worldwide fortification of edible salt has been undertaken to offset the iodine deficiency. Hypothyroidism is characterized by decreased levels of thyroid hormone. With respect to oral involvement, there can be evident thickening of lips due to deposition of glycosaminoglycans in the subcutaneous tissues. Similarly, macroglossia of tongue can be seen because of the same reason. If children are affected, there may be delayed eruption of teeth without any influence on teeth formation [53].

Hyperthyroidism in adults can result in diffuse brown pigmentation of the gingiva, buccal mucosa, palate, and tongue similar to Addison's disease. The mechanism through which the stimulation of melanin synthesis occurs is yet unclear but pigmentation tends to resolve with the treatment of thyroid abnormality [79]. 


\section{Detection of Trace Elements and Assessment of Nutritional Status}

This was done as follows:

(1) Though various methods have been employed to determine the presence of trace elements, it is a cumbersome and nonfruitful job due to their wide distribution within the living tissues and enzyme systems. Colorimetric and spectrographic methods are used commonly to analyse the amount of trace elements. Typically, spectroscopy and electrochemical methods are preferred for solitary element analysis whereas neutron activation analysis and spectroscopic methods are used for determination of more than one element [11].

(2) The most easily determined deficiency is of iron which can be determined by performing laboratory tests [80]. Bone marrow smear containing no stainable iron is definitive. Elevated total iron-binding capacity, low serum iron level, and a low serum ferritin concentration are considered diagnostic for iron deficiency. Recently, newer approaches like erythrocyte zinc porphyrin assay have also been used in primary screening tests for assessing iron status [81].

(3) The reported optimal plasma or serum ratio between copper and zinc is $0.70-1.00$. Diagnosing zinc deficiency is a persistent challenge as mentioned before in the paper. Plasma or serum zinc levels are the most commonly used indices for evaluating zinc deficiency. Severe $\mathrm{Cu}$ deficiency can be found by testing for low plasma or serum copper levels, low ceruloplasmin, and low superoxide dismutase levels but these are not very sensitive tests and fail to determine marginal copper deficiency $[16,82]$.

(4) The assessment of the iodine nutritional status of a population or group living in an area or region suspected to be iodine-deficient area can be performed by assessment of the goitre rate, measurement of urinary iodine excretion, and determination of the level of blood T3, T4, or TSH.

(5) Tissue chromium stores apparently do not truly reflect the blood chromium; thus, serum chromium concentration is not a good indicator of chromium status. It has been postulated that serum chromium levels lower than $0.14-0.15 \mathrm{ng} / \mathrm{mL}$ indicate the presence of a severe chromium deficiency. Excessive exposure of individual to chromium via occupation or accident may be reflected by elevated serum chromium.

(6) Different tissues such as blood, hair, and nails have been analysed for determining the nutritional status of selenium. Generally, these tissues can provide a sound appraisal of selenium status if dietary selenium intake is relatively uniform.

(7) Tissue levels status of other trace elements in normal individuals is difficult to determine.
TABLE 2: Trace elements and preventive medicine [5].

\begin{tabular}{ll}
\hline Prevention & Trace element involved \\
\hline $\begin{array}{l}\text { Predisposition to anemia } \\
\text { Reduction in antioxidant }\end{array}$ & $\begin{array}{l}\text { Iron, cobalt, copper } \\
\text { potential }\end{array}$ \\
$\begin{array}{l}\text { Zinc, iron, manganese, } \\
\text { selenium, copper } \\
\text { cause }\end{array}$ & $\begin{array}{l}\text { Zinc, copper, selenium, } \\
\text { chromium }\end{array}$ \\
Immunodeficiency & Zinc, iron, copper, selenium \\
Increased carcinogenicity & Zinc, copper, selenium \\
Promoted atherosclerosis & Zinc, selenium, iron, copper, \\
chromium \\
Increased incidence of & Chromium, zinc, selenium \\
Predisposition to taste & \\
disorder & Zinc \\
Predisposition to dental caries & Fluorine, molybdenum? \\
Predisposition to goiter & Iodine \\
\hline
\end{tabular}

\section{Conclusion}

It is one of the most difficult tasks to diagnose trace element deficiencies nutritionally as well as clinically. The deficient intake of an essential trace element may diminish significant biological functions within tissues and restoration of physiological levels of that element relieves the impaired function or prevents impairment. The human body has an elaborate system for managing and regulating the amount of key trace metals circulating in blood and stored in cells. The abnormal levels of these trace elements may develop when the body fails to function properly or there are improper levels in dietary sources. There are convincing lines of evidence that a diet rich in antioxidants and essential minerals is indispensable for a healthy mind and body. Preventive medicine in the recent years has gained more attention than anything else as quoted aptly, "prevention is better than cure." Selective reproduction of association between preventive medicine and various trace elements has been presented in Table 2 [5]. Oral and general health cannot be viewed independently and as a matter of fact the oral cavity can mirror the systemic health effectively. The combination of various micronutrients and trace elements has been used as a treatment strategy for oral diseases like oral leukoplakia, oral submucous fibrosis, oral cancer, and so forth as their collective outcome is more beneficial as compared to solitary application. Hence, knowledge of the clinical aspects of trace elements is becoming requisite for general as well as oral physicians.

\section{Competing Interests}

The authors declare that they have no competing interests.

\section{References}

[1] I. L. Chapple, G. R. Brock, M. R. Milward, N. Ling, and J. B. Matthews, "Compromised GCF total antioxidant capacity in periodontitis: cause or effect?" Journal of Clinical Periodontology, vol. 34, no. 2, pp. 103-110, 2007. 
[2] C. O. Enwonwu, R. S. Phillips, and W. A. Falkler Jr., "Nutrition and oral infectious diseases: state of the science," Compendium of Continuing Education in Dentistry, vol. 23, no. 5, pp. 431-448, 2002.

[3] P. J. Moynihan, "The role of diet and nutrition in the etiology and prevention of oral diseases," Bulletin of the World Health Organization, vol. 83, no. 9, pp. 694-699, 2005.

[4] M. Chen, R. M. Andersen, D. E. Barmes, M. H. Leclerq, and S. V. Little, Comparing Oral Health Systems: A Second International Collaborative Study, World Health Organization, Geneva, Switzerland, 1997.

[5] O. Wada, "What are trace elements? Their deficiency and excess states," Japan Medical Association Journal, vol. 47, no. 8, pp. 351358, 2004.

[6] WHO, Trace-Elements in Human Nutrition. Report of a WHO Expert Committee, WHO Technical Report Series, No. 532, World Health Organization, Geneva, Switzerland, 1973.

[7] E. Frieden, "New perspectives on the essential trace elements," Journal of Chemical Education, vol. 62, no. 11, pp. 915-923, 1985.

[8] E. Frieden, "The evolution of metals as essential elements [with special reference to iron and copper]," in Protein-Metal Interactions, M. Friedman, Ed., vol. 48 of Advances in Experimental Medicine and Biology, pp. 1-31, Springer, New York, NY, USA, 1974.

[9] M. S. Willis, S. A. Monaghan, M. L. Miller et al., "Zinc-induced copper deficiency: a report of three cases initially recognized on bone marrow examination," American Journal of Clinical Pathology, vol. 123, no. 1, pp. 125-131, 2005.

[10] J. Osredkar and N. Sustar, "Copper and zinc, biological role and significance of copper/zinc imbalance," Journal of Clinical Toxicology, 2011.

[11] C. Minoia, E. Sabbioni, P. Apostoli et al., "Trace element reference values in tissues from inhabitants of the European community I. A study of 46 elements in urine, blood and serum of Italian subjects," Science of the Total Environment, vol. 95, pp. 89-105, 1990.

[12] S. J. Adelstein and B. L. Vallee, "Copper metabolism in man," The New England Journal of Medicine, vol. 265, pp. 892-897, 1961.

[13] E. D. Harris, "Copper homeostasis: the role of cellular transporters," Nutrition Reviews, vol. 59, no. 9, pp. 281-285, 2001.

[14] J. L. Groff, S. S. Gropper, and S. M. Hunt, Advanced Nutrition and Human Metabolism, West Publishing Company, New York, NY, USA, 1995.

[15] S. J. Lippard and J. M. Berg, Principles of Bioinorganic Chemistry, University Science Books, Mill Valley, Calif, USA, 1994.

[16] M. Araya, F. Pizarro, M. Olivares, M. Arredondo, M. González, and M. Méndez, "Understanding copper homeostasis in humans and copper effects on health," Biological Research, vol. 39, no. 1, pp. 183-187, 2006.

[17] M. Bonham, J. M. O’Connor, B. M. Hannigan, and J. J. Strain, "The immune system as a physiological indicator of marginal copper status?” British Journal of Nutrition, vol. 87, no. 5, pp. 393-403, 2002.

[18] D. Rakel, Integrative Medicine, Saunders Elsevier, 2nd edition, 2007.

[19] C. D. Davis, "Low dietary copper increases fecal free radical production, fecal water alkaline phosphatase activity and cytotoxicity in healthy men," Journal of Nutrition, vol. 133, no. 2, pp. 522-527, 2003.

[20] Y. Christen, "Oxidative stress and Alzheimer disease," The American Journal of Clinical Nutrition, vol. 71, no. 2, pp. 621s629s, 2000.
[21] D. L. Watts, “The nutritional relationships of copper," Journal of Orthomolecular Medicine, vol. 4, no. 2, pp. 99-108, 1989.

[22] B. L. Odell, Biochemical Basis of the Clinical Effects of Copper Deficiency, Alan R Liss Inc, New York, NY, USA, 1982.

[23] W. Harless, E. Crowell, and J. Abraham, "Anemia and neutropenia associated with copper deficiency of unclear etiology," American Journal of Hematology, vol. 81, no. 7, pp. 546-549, 2006.

[24] C. R. Trivedy, K. A. A. S. Warnakulasuriya, T. J. Peters, R. Senkus, V. K. Hazarey, and N. W. Johnson, "Raised tissue copper levels in oral submucous fibrosis," Journal of Oral Pathology and Medicine, vol. 29, no. 6, pp. 241-248, 2000.

[25] V. D. Desai, M. V. S. Kumar, R. J. Bathi, I. Gaurav, and R. Sharma, "Molecular analysis of trace elements in oral submucous fibrosis and future perspectives," Universal Research Journal of Dentistry, vol. 4, no. 1, pp. 26-35, 2014.

[26] P. Rajalalitha, "Molecular pathogenesis of OSMF," Journal of Oral Pathology and Medicine, vol. 34, no. 6, pp. 321-328, 2005.

[27] L. Prashanth, K. K. Kattapagari, R. T. Chitturi, V. R. Baddam, and L. K. Prasad, "A review on role of essential trace elements in health and disease," Journal of NTR University of Health Sciences, vol. 4, pp. 75-85, 2015.

[28] R. A. Wapnir, Protein Nutrition and Mineral Absorption, CRC Press, Boca Raton, Fla, USA, 1990.

[29] C. C. Pfeiffer and E. R. Braverman, "Zinc, the brain and behavior," Biological Psychiatry, vol. 17, no. 4, pp. 513-532, 1982.

[30] M. R. Broadley, P. J. White, J. P. Hammond, I. Zelko, and A. Lux, "Zinc in plants," New Phytologist, vol. 173, no. 4, pp. 677-702, 2007.

[31] E. N. Whitney and S. R. Rolfes, Understanding Nutrition, Thomson Learning, Boston, Mass, USA, 10th edition, 2010.

[32] M. Valko, H. Morris, and M. T. D. Cronin, "Metals, toxicity and oxidative stress," Current Medicinal Chemistry, vol. 12, no. 10, pp. 1161-1208, 2005.

[33] H. H. Sandstead, "Understanding zinc: recent observations and interpretations," Journal of Laboratory and Clinical Medicine, vol. 124, no. 3, pp. 322-327, 1994.

[34] T. J. McCarthy, J. J. Zeelie, and D. J. Krause, "The antimicrobial action of zinc ion/antioxidant combinations," Journal of Clinical Pharmacy and Therapeutics, vol. 17, no. 1, pp. 51-54, 1992.

[35] N. W. Solomons, "Mild human zinc deficiency produces an imbalance between cell-mediated and humoral immunity," Nutrition Reviews, vol. 56, no. 1, pp. 27-28, 1998.

[36] A. S. Prasad, “Zinc: an overview," Nutrition, vol. 11, no. 1, pp. 9399, 1995.

[37] C. A. Heyneman, "Zinc deficiency and taste disorders," Annals of Pharmacotherapy, vol. 30, no. 2, pp. 186-187, 1996.

[38] A. S. Prasad, F. W. J. Beck, S. M. Grabowski, J. Kaplan, and R. H. Mathog, "Zinc deficiency: changes in cytokine production and T-cell subpopulations in patients with head and neck cancer and in noncancer subjects," Proceedings of the Association of American Physicians, vol. 109, no. 1, pp. 68-77, 1997.

[39] K. Simmer and R. P. Thompson, "Zinc in the fetus and newborn," Acta Paediatrica Scandinavica. Supplement, vol. 319, pp. 158-163, 1985.

[40] N. Fabris and E. Mocchegiani, "Zinc, human diseases and aging," Aging Clinical and Experimental Research, vol. 7, no. 2, pp. 77-93, 1995.

[41] W. Maret and H. H. Sandstead, "Zinc requirements and the risks and benefits of zinc supplementation," Journal of Trace Elements in Medicine and Biology, vol. 20, no. 1, pp. 3-18, 2006. 
[42] Institute of Medicine and Food and Nutrition Board, Dietary Reference Intakes for Vitamin A, Vitamin K, Arsenic, Boron, Chromium, Copper, Iodine, Iron, Manganese, Molybdenum, Nickel, Silicon, Vanadium, and Zinc, National Academy Press, Washington, DC, USA, 2001.

[43] P. E. Milbury and A. C. Richer, Understanding the Antioxidant Controversy: Scrutinizing the "Fountain of Youth", Greenwood Publishing Group, 2008.

[44] R. J. Lynch, "Zinc in the mouth, its interactions with dental enamel and possible effects on caries; a review of the literature," International Dental Journal, vol. 61, supplement 3, pp. 46-54, 1984.

[45] R. I. Henkin, “Zinc in taste function," Biological Trace Element Research, vol. 6, no. 3, pp. 263-280, 1984.

[46] M. Das and R. Das, "Need of education and awareness towards zinc supplementation: a review," International Journal of Nutrition and Metabolism, vol. 4, no. 3, pp. 45-50, 2012.

[47] A. Jayadeep, K. Raveendran Pillai, S. Kannan et al., "Serum levels of copper, zinc, iron and ceruplasmin in oral leukoplakia and squamous cell carcinoma," Journal of Experimental \& Clinical Cancer Research, vol. 16, no. 3, pp. 295-300, 1997.

[48] J. G. Ray, R. Ghosh, D. Mallick et al., "Correlation of trace elemental profiles in blood samples of Indian patients with leukoplakia and oral submucous fibrosis," Biological Trace Element Research, vol. 144, no. 1-3, pp. 295-305, 2011.

[49] S. J. Mulware, "Trace elements and carcinogenicity: a subject in review," 3 Biotech, vol. 3, no. 2, pp. 85-96, 2013.

[50] D. M. Vasudevan and S. Sreekumari, Text Book of Biochemistry for Medical Students, Jaypee, New Delhi, India, 5th edition, 2007.

[51] E. Frieden, "The chemical elements of life," Scientific American, vol. 227, no. 1, pp. 52-60, 1972.

[52] U. Satyanarayana and U. Chakrapani, Essentials of Biochemistry, Book and Allied, Kolkata, India, 2nd edition, 2008.

[53] B. D. Neville, D. D. Damm, C. M. Allen, and J. E. Bouquot, Oral and Maxillofacial Pathology, Elsevier, Chennai, India, 3rd edition, 2009.

[54] P. T. Bhattacharya, T. Khaitan, S. B. Sarkar, and R. Sinha, "Oral submucous fibrosis secondary to iron deficiency anemia: a case report, etiopathogenesis and management," The Journal of Nutrition, Health and Aging, vol. 20, no. 2, pp. 205-208, 2016.

[55] D. G. Barceloux, "Cobalt," Journal of Toxicology-Clinical Toxicology, vol. 37, no. 2, pp. 201-216, 1999.

[56] N. Yamagata, S. Murata, and T. Torii, "The cobalt content of human body," Journal of Radiation Research, vol. 3, no. 1, pp. $4-8,1962$.

[57] N. A. Taylor and T. S. Marks, "Food and nutrition board recommended daily allowances," Journal of Human Nutrition and Dietetics, vol. 32, pp. 165-177, 1974.

[58] J. M. Christensen, O. M. Poulsen, and M. Thomsen, "A shortterm cross-over study on oral administration of soluble and insoluble cobalt compounds: sex differences in biological levels," International Archives of Occupational and Environmental Health, vol. 65, no. 4, pp. 233-240, 1993.

[59] K. Czarnek, S. Terpiłowska, and A. K. Siwicki, "Selected aspects of the action of cobalt ions in the human body," Central European Journal of Immunology, vol. 40, no. 2, pp. 236-242, 2015.

[60] N. Lombaert, D. Lison, P. Van Hummelen, and M. KirschVolders, "In vitro expression of hard metal dust (WC-Co)responsive genes in human peripheral blood mononucleated cells," Toxicology and Applied Pharmacology, vol. 227, no. 2, pp. 299-312, 2008.
[61] W. G. Shafer, M. K. Hine, and B. M. Levy, A Textbook of Oral Pathology, Elsevier India, Chennai, India, 4th edition, 2004.

[62] S. B. Ismail, S. K. S. Kumar, and R. B. Zain, "Oral lichen planus and lichenoid reactions: etiopathogenesis, diagnosis, management and malignant transformation," Journal of Oral Science, vol. 49, no. 2, pp. 89-106, 2007.

[63] Z. Krejpcio, "Essentiality of chromium for human nutrition and health," Polish Journal of Environmental Studies, vol. 10, no. 6, pp. 399-404, 2001.

[64] World Health Organization, Trace Elements in Human Nutrition and Health, World Health Organization, Geneva, Switzerland, 1996.

[65] J. M. Nguta, Essential Trace Elements: Trace Elements in Human and Animal Health, LAP, Lambert Academic Publishing, Saarbrücken, Germany, 2010.

[66] N. Kulkarni, K. Kalele, M. Kulkarni, and R. Kathariya, "Trace elements in oral health and disease: an updated review," Journal of Dental Research and Review, vol. 1, no. 2, pp. 100-104, 2014.

[67] M. P. Rayman, "Selenium and human health," The Lancet, vol. 379, no. 9822, pp. 1256-1268, 2012.

[68] A. B. Serwin, W. Wasowicz, J. Gromadzinska, and B. Chodynicka, "Selenium status in psoriasis and its relations to the duration and severity of the disease," Nutrition, vol. 19, no. 4, pp. 301-304, 2003.

[69] H. W. Kuo, S. F. Chen, C. C. Wu, D. R. Chen, and J. H. Lee, "Serum and tissue trace elements in patients with breast cancer in Taiwan," Biological Trace Element Research, vol. 89, no. 1, pp. $1-11,2002$.

[70] J. R. Arthur and G. R. Beckett, "Selenium deficiency and thyroid hormone metabolism," in Selenium in Biology and Medicine, A. Wendell, Ed., pp. 90-95, Springer, Berlin, Germany, 1989.

[71] B. Contempre, J. E. Dumont, B. Ngo, C. H. Thilly, A. T. Diplock, and J. Vanderpas, "Effect of selenium supplementation in hypothyroid subjects of an iodine and selenium deficient area: the possible danger of indiscriminate supplementation of iodine-deficient subjects with selenium," Journal of Clinical Endocrinology and Metabolism, vol. 73, no. 1, pp. 213-215, 1991.

[72] N. Swain and J. G. Ray, "Altered trace element level and antioxidant activity in whole blood of oral leukoplakia and cancer patients in comparison with healthy controls," International Journal of Oral \& Maxillofacial Pathology, vol. 2, no. 2, pp. 26, 2011.

[73] Z. Jahangard-Rafsanjani, K. Gholami, M. Hadjibabaie et al., "The efficacy of selenium in prevention of oral mucositis in patients undergoing hematopoietic SCT: a randomized clinical trial," Bone Marrow Transplantation, vol. 48, no. 6, pp. 832-836, 2013.

[74] M. P. Coughlan, "The role of molybdenum in human biology," Journal of Inherited Metabolic Disease, vol. 6, supplement 1, pp. 70-77, 1983.

[75] N. F. Suttle, "Recent studies of the copper-molybdenum antagonism," Proceedings of the Nutrition Society, vol. 33, no. 3, pp. 299-305, 1974.

[76] M. Curzon, J. Kubota, and B. Bibby, "Environmental effects of molybdenum on caries," Journal of Dental Research, vol. 50, no. 1, pp. 74-77, 1971.

[77] S. Venturi and M. Venturi, "Iodine in evolution of salivary glands and in oral health," Nutrition and Health, vol. 20, no. 2, pp. 119-134, 2009.

[78] J. Littleton and B. Frohlich, "Fish-eaters and farmers: dental pathology in the Arabian Gulf," American Journal of Physical Anthropology, vol. 92, no. 4, pp. 427-447, 1993. 
[79] M. S. Greenberg, M. Glick, and J. A. Ship, Burket's Oral Medicine, CBS Publisher, New Delhi, India, 11th edition, 2008.

[80] C. Brugnara, "Iron deficiency and erythropoiesis: new diagnostic approaches," Clinical Chemistry, vol. 49, no. 10, pp. 1573-1578, 2003.

[81] R. F. Labbé and A. Dewanji, "Iron assessment tests: transferrin receptor vis-à-vis zinc protoporphyrin," Clinical Biochemistry, vol. 37, no. 3, pp. 165-174, 2004.

[82] L. Goldman and D. Ausiello, Cecil Medicine, Saunders Elsevier, Philadelphia, Pa, USA, 23rd edition, 2007.

[83] K. Park, Park's Textbook of Preventive and Social Medicine, Banarsidas Bhanot, Jabalpur, India, 21st edition, 2011. 


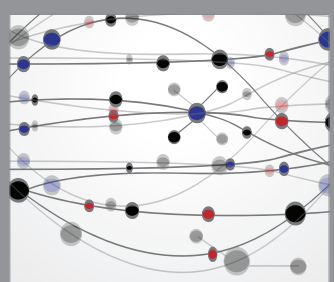

The Scientific World Journal
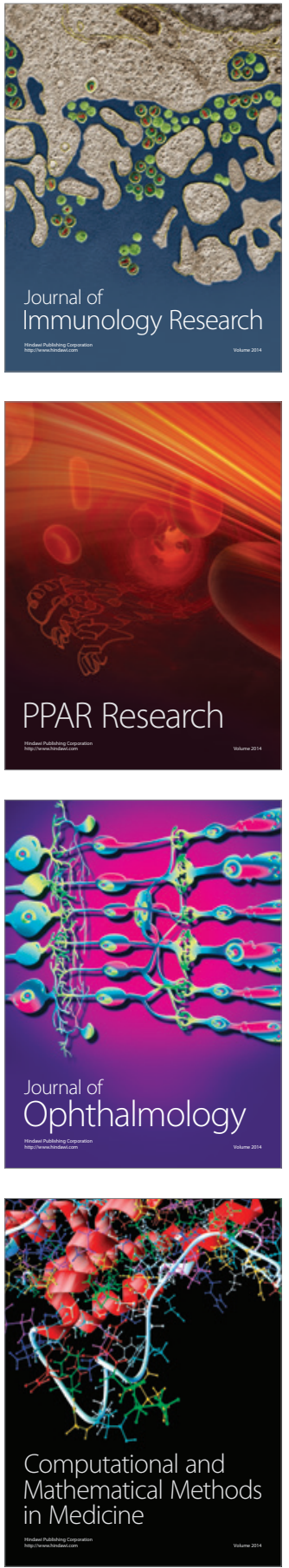

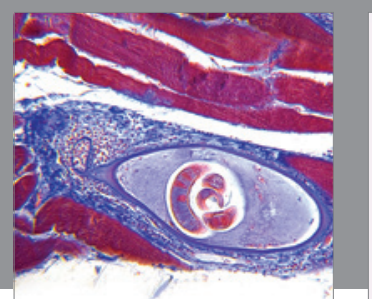

Gastroenterology Research and Practice

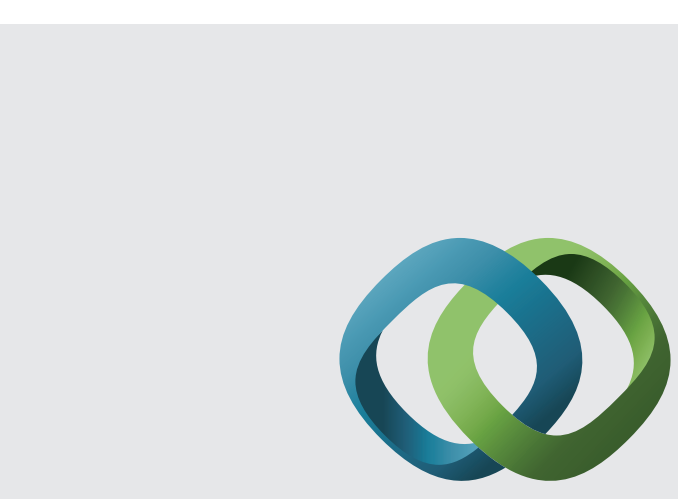

\section{Hindawi}

Submit your manuscripts at

http://www.hindawi.com
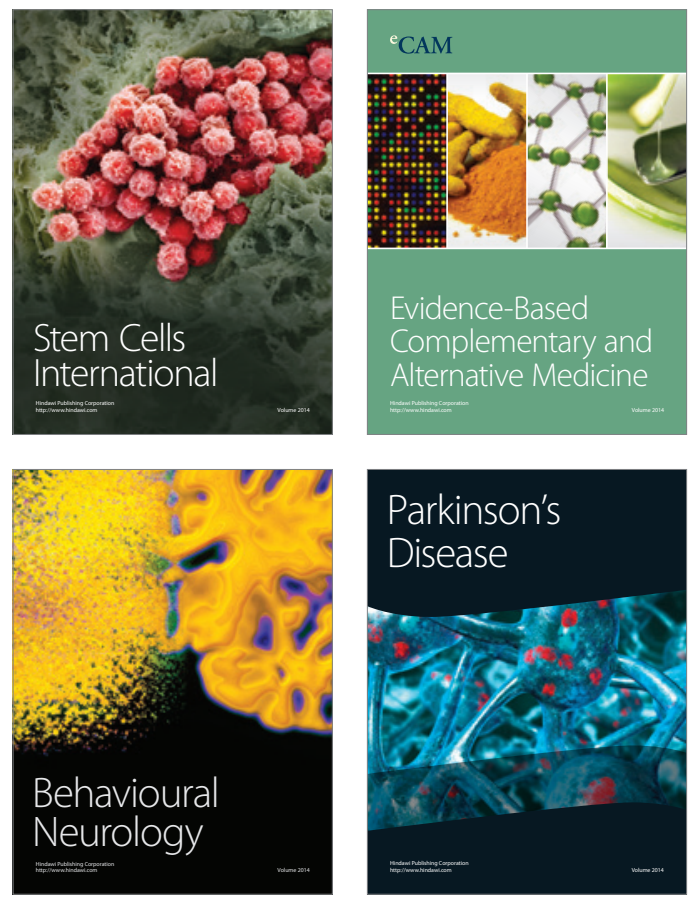
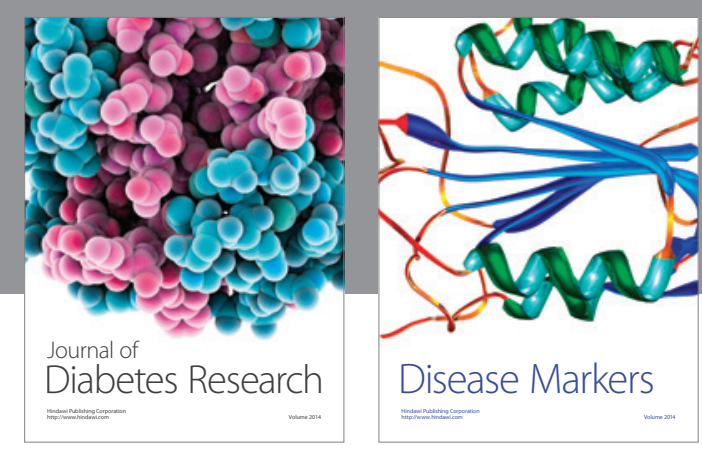

Disease Markers
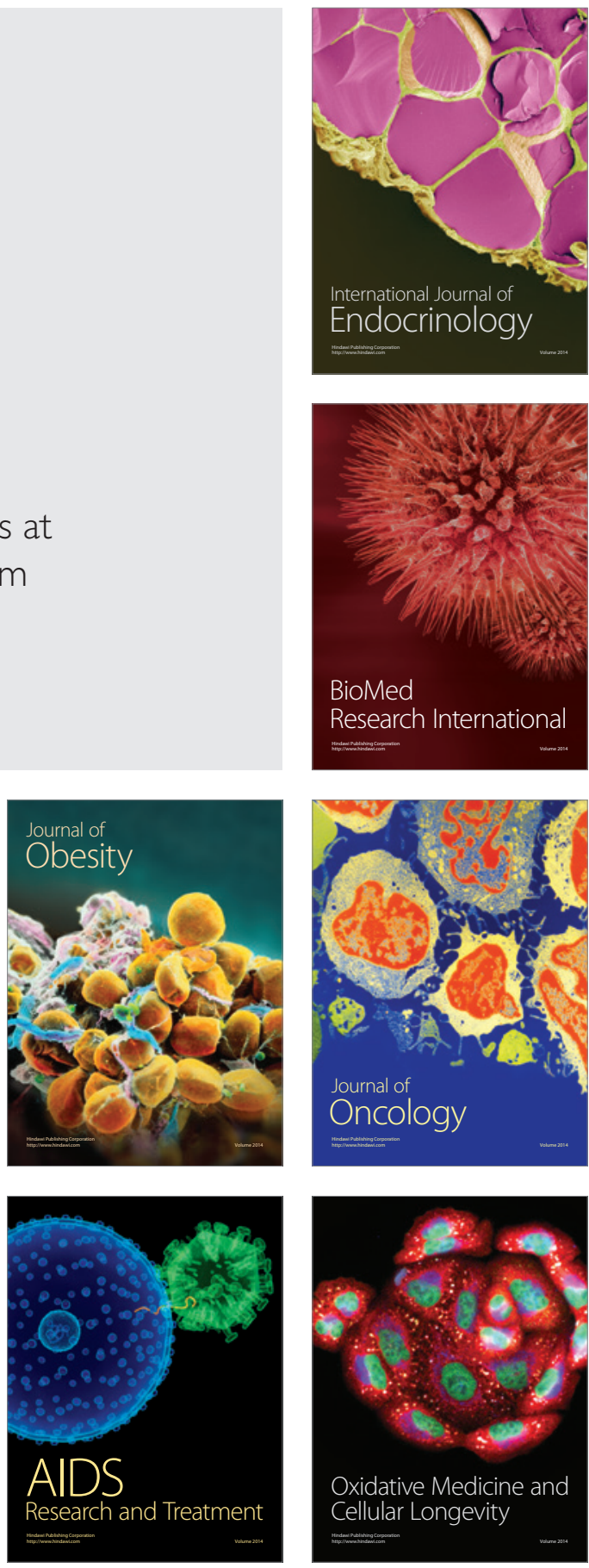